\title{
MicroRNA as Crucial Regulators of Gene Expression in Estradiol-Treated Human Endothelial Cells
}

\author{
Xavier Vidal-Gómez ${ }^{\mathrm{a}, \mathrm{b}}$, Daniel Pérez-Cremades ${ }^{\mathrm{a}, \mathrm{b}} \quad$ Ana Mompeón ${ }^{\mathrm{a}, \mathrm{b}}$ \\ Ana Paula Dantas ${ }^{c}$ Susana Novella ${ }^{a, b}$ Carlos Hermenegildo ${ }^{a, b}$ \\ aDepartment of Physiology, Faculty of Medicine and Dentistry, University of Valencia, Valencia, 'bINCLIVA \\ Biomedical Research Institute, Valencia, Institut Clinic Cardiovascular (ICCV), Institut d'Investigacions \\ Biomèdiques August Pi i Sunyer (IDIBAPS), Barcelona, Spain
}

\section{Key Words}

MiRNA • Estradiol • Estrogen receptors • Epigenetic regulation • Endothelial cells

\begin{abstract}
Background/Aims: Estrogen signalling plays an important role in vascular biology as it modulates vasoactive and metabolic pathways in endothelial cells. Growing evidence has also established microRNA (miRNA) as key regulators of endothelial function. Nonetheless, the role of estrogen regulation on miRNA profile in endothelial cells is poorly understood. In this study, we aimed to determine how estrogen modulates miRNA profile in human endothelial cells and to explore the role of the different estrogen receptors (ER $\alpha, E R \beta$ and GPER) in the regulation of miRNA expression by estrogen. Methods: We used miRNA microarrays to determine global miRNA expression in human umbilical vein endothelial cells (HUVEC) exposed to a physiological concentration of estradiol (E2; $1 \mathrm{nmol} / \mathrm{L}$ ) for 24 hours. miRNAgene interactions were computationally predicted using Ingenuity Pathway Analysis and changes in miRNA levels were validated by qRT-PCR. Role of ER in the E2-induced miRNA was additionally confirmed by using specific ER agonists and antagonists. Results: miRNA array revealed that expression of 114 miRNA were significantly modified after E2 exposition. Further biological pathway analysis revealed cell death and survival, lipid metabolism, reproductive system function, as the top functions regulated by E2. We validated changes in the most significantly increased (miR-30b-5p, miR-487a-5p, miR-4710, miR-501-3p) and decreased (miR-378h and miR-1244) miRNA and the role of ER in these E2-induced miRNA was determined. Results showed that both classical, ER $\alpha$ and ER $\beta$, and membrane-bound ER, GPER, differentially regulated specific miRNA. In silico analysis of validated miRNA promoters identified specific ER binding sites. Conclusion: Our findings identify differentially expressed miRNA pathways linked to E2 in human endothelial cells through ER, and provide new insights by which estrogen can modulate endothelial function.

X. Vidal-Gómez and D. Pérez-Cremandes contributed equally to this work.
\end{abstract}

Susana Novella

KARGER 


\section{Introduction}

$17 \beta$-Estradiol (E2) is the most important estrogen, which exerts its action mainly through activation of estrogen receptors (ER) present in different tissues, including endothelium [1]. Endothelial cells are involved in the regulation of vascular function and express both types of nuclear estrogen receptors (ER $\alpha$ and $E R \beta)$ as well as the G protein-coupled estrogen receptor (GPER) [2].

Women during their fertile ages present less incidence of cardiovascular diseases than age-matched men and this advantage disappears after menopause, attributing a beneficial effect to estrogens [3]. Protective effects by estrogen on cardiovascular system have been related to increased vasodilation, anti-inflammatory action, regulation of vascular smooth muscle cell proliferation, and attenuation of atherosclerotic processes [4]. In this regard, the E2-mediated vasoprotective role through an increase of endothelial-derived factors has been described to be ER-dependent [5-7].

microRNA (miRNA) are small, non-coding RNA enrolled in gene expression regulation at post-transcriptional level and are predicted to regulate two-thirds of the human genome, suggesting that miRNA modulate physiological relevant processes [8]. miRNA regulate protein translation by targeting their complementary messenger RNA (mRNA) [9] and by repressing translation or degrading target mRNA. Most miRNA are located within the cell, although some of them have also been found circulating in body fluids [10]. Nowadays, there are many studies focused in their role in different clinical conditions, including cardiovascular diseases, and their potential as clinical biomarkers [11,12].

The effects of E2 on gene [5,13] and protein expression [14] have already been reported in endothelial cells. Few recent studies in gynaecological cancer research have described an association of miRNA and estrogen signalling. Most of them have described the role of miRNA to regulate ER expression and estrogen-associated molecules [15, 16]. How E2 may interfere with the whole miRNA expression profile in the cardiovascular system is largely unknown. In this regard, our study aims to determine changes in miRNA expression profile in cultured human umbilical vein endothelial cells (HUVEC) exposed to physiological concentration of E2. By using microarray technology, we sought to provide new information about the molecular mechanisms implicated in the E2 regulation of vascular function. We also investigate the implication of different ER in E2-dependent miRNA regulation.

\section{Materials and Methods}

\section{Cell culture and experimental design}

Primary HUVEC cultures were obtained by collagenase treatment of human umbilical cord veins from Hospital Clínico of Valencia as previously described [17]. Briefly, HUVEC were obtained from umbilical veins by enzymatic digestion with $0.1 \mathrm{mg} / \mathrm{mL}$ collagenase (Life Technologies, Carlsbad, CA, USA) and cultured in Medium 199 (Sigma-Aldrich, Tres Cantos, Madrid, Spain) supplemented with 20\% fetal bovine serum (GIBCO, Barcelona, Spain), endothelial cell growth supplement (Sigma-Aldrich) and heparin sodium salt (Sigma-Aldrich) at $37{ }^{\circ} \mathrm{C}$ with $5 \% \mathrm{CO}_{2}$. Cells were identified as endothelial by their characteristic cobblestone morphology and the presence of von Willebrand factor by immunocytochemistry using a specific antibody (F-3520; Sigma-Aldrich) as previously described [18]. HUVEC from passages 3 to 4 were seeded onto gelatin-coated 6-well plates. When they reached confluence, culture medium was exchanged for a phenol red-free Medium 199 (Sigma-Aldrich) supplemented with 20\% charcoal/dextran-treated fetal bovine serum (GIBCO) to avoid any steroid activity and maintained for 24 hours.

Cells were exposed for $24 \mathrm{~h}$ to $1 \mathrm{nmol} / \mathrm{L}$ of E2 (Sigma-Aldrich). In some experiments, to study the role of sex hormone receptors, cells were previously exposed (60 minutes before E2) to the unspecific antagonist of ER $\alpha$ and ER $\beta$, ICI 182780 ( $1 \mu \mathrm{mol} / \mathrm{L}$; Biogen, Madrid, Spain), the specific ER $\alpha$ antagonist methyl-piperidinopyrazole (MPP) ( $1 \mu \mathrm{mol} / \mathrm{L}$; Tocris Bioscience, Ellisville, MI, USA) and to the specific GPER antagonist G15 (1 $\mu \mathrm{mol} / \mathrm{L}$; Tocris Bioscience). In another set of experiments, cells were exposed for 24 hours to the selective ER $\alpha$ agonist PPT ( $1 \mathrm{nmol} / \mathrm{L}$; Tocris Bioscience), the selective ER $\beta$ agonist DPN ( $1 \mathrm{nmol} / \mathrm{L}$; Tocris Bioscience), 


\section{Cellular Physiology Cell Physiol Biochem 2018:45:1878-1892 \begin{tabular}{l|l} 
and Biochemistry & DOI: 10.1159/000487910 \\
Published online: March 05, 2018 & $\begin{array}{l}\text { ( ) 2018 The Author(s). Published by S. Karger AG, Basel } \\
\text { www.karger.com/cpb }\end{array}$
\end{tabular} \\ Published online: Mach}

or the selective GPER agonist G1 (1 nmol/L; Tocris Bioscience). Control cells were exposed to the same vehicle of cells treated with E2 (0.1\% etanol) or antagonist $(0.1 \%$ DMSO). All concentrations and times selected were chosen taking into account previous studies $[5,19,20]$. A schematic workflow of the experimental design is provided in Fig. 1.

The research protocol was approved by the Ethical Committee of Clinical Research of the INCLIVA, Hospital Clínico of Valencia, Spain, conforms with the principles outlined in the Declaration of Helsinki, and written informed consent was obtained from all donors.

RNA isolation and microRNA expression analysis

To perform microarray experiment, HUVEC from 12 separate cultures were exposed to control $(0.1 \%$ ethanol) and 1 nmol/L E2 treatments for $24 \mathrm{~h}$. Total RNA including small non-coding RNA was extracted by using the QIAzol reagent and miRNeasy Mini kit (Qiagen, L'Hospitalet de Llobregat, Spain) following the manufacturer's instructions. RNA extracted from 3 control- or 3 E2-treated cultured flasks obtained from three different cultures were pooled, achieving four biological replicates of the control and four that were treated with E2. Therefore, a total number of 8 microarrays were developed ( 4 control pools, named C1, C2, C3, C4 and 4 E2treated pools named E1, E2, E3 and E4).

The concentration and purity of the RNA obtained was measured as the OD260/280 ratio using a GeneQuant Pro spectrophotometer (GE Healthcare, Madrid, Spain). RNA integrity was determined by capillary electrophoresis using an RNA 6000 Nano Lab-on-a-Chip kit and a Bioanalyzer 2100 (Agilent Technologies, Santa Clara, CA, USA). Only RNA extracts with an integrity value of 7 or higher were used for further analysis.

Small non-coding RNA expression profiling was performed using a GeneChip miRNA 4.0 Array (Affymetrix, Santa Clara, CA, USA). Microarray experiments were conducted according to the manufacturer's protocol. Briefly, 300 ng of total RNA was labelled with a FlashTag Biotin HSR RNA Labeling kit from Genisphere. The labelling reaction was hybridized onto the miRNA array in an Affymetrix Hybridization Oven 645 at $48^{\circ} \mathrm{C}$ and $60 \mathrm{rpm}$ for $18 \mathrm{~h}$. The arrays were stained using a Fluidics Station 450 with the fluidics script FS450_0002 (Affymetrix) and then scanned on a GeneChip Scanner 3, 000 7G (Affymetrix), using the GeneChip Command Console Software supplied by Affymetrix to perform gene expression analysis. miRNA probe outliers were defined and further analysed as manufacturer's instructions, and quality control, as well as data summarization and normalization, was carried out using the web-based miRNA QC Tool (www. affymetrix.com).

Resulting data files (.cel) were used to analyse significant differences in miRNA expression profile between E2 and control groups using Partek Genomic Suite (Partek Inc., St Louise, MO, USA) [21]. Partek Genomic Suite was also used to identify global differences between samples by Principal Component Analysis (PCA) measurement. Distance between plotted samples is related to similarity between them. Hierarchical Cluster was determined to analyse expression profiles of different samples, in which the branches represented in a dendrogram that are close to each other had similar miRNA expression patterns.

Analysis of miRNA-predicted target interaction

miRNA significantly regulated by estrogen were analysed using Ingenuity Pathways Analysis (IPA) software (Ingenuity Systems, Redwood City, CA, USA; Winter release 2016) as previously described in [5, 22]. 


\section{Cellular Physiology Cell Physiol Biochem 2018;45:1878-1892 \begin{tabular}{l|l} 
and Biochemistry Published online: March 05, 2018 & $\begin{array}{l}\text { (c) } 2018 \text { The Author(s). Published by S. Karger AG, Basel } \\
\text { www.karger.com/cpb }\end{array}$
\end{tabular} \\ Vidal-Gómez et al.: Estradiol Regulates Endothelial MiRNA}

This software uses computational algorithms to identify miRNA-targets as well as putative cellular networks between the predicted targets. IPA microRNA Target Filter tool enables prioritization of experimentally validated and predicted mRNA targets according to three different miRNA target prediction programs (TargetScan, miRecords and Ingenuity Knowledge Base) and the available database of experimentally supported miRNA targets TarBase.

Quantitative real-time PCR

The TaqMan miRNA Assay system (Applied Biosystems, Foster City, CA, USA) was used to validate changes in miRNA levels. For reverse transcription (RT) reactions, RNA (300 ng) was reverse transcribed using the TaqMan MicroRNA Reverse Transcription Kit (Applied Biosystems) according to the manufacturer's instructions. Specific RT primers from each assay were added to $15 \mu \mathrm{L}$ reaction volumes. miRNA levels were determined by quantitative real-time PCR (qRT-PCR) analysis using an ABI Prism 7900 HT Fast Real-Time PCR System (Applied Biosystems). Gene-specific primer pairs and probes (Applied Biosystems) for miR30b-5p (000602), miR-4710 (463602_mat), miR-1244 (002791), miR-487a-5p (467005_mat), miR-501-3p (002435), miR-378h (464554_mat), were used together with TaqMan Universal PCR Master Mix (Applied Biosystems) and $1 \mu \mathrm{L}$ of reverse-transcribed product in $20 \mu \mathrm{L}$ reaction volumes. PCR conditions were $10 \mathrm{~min}$ at $95^{\circ} \mathrm{C}$ for enzyme activation, followed by 60 two-step cycles $\left(15 \mathrm{~s}\right.$ at $95^{\circ} \mathrm{C}$; $1 \mathrm{~min}$ at $\left.60^{\circ} \mathrm{C}\right)$. The levels of RNU48 (001006) expression were measured in all samples to normalize differences in RNA input, RNA quality, and reverse transcription efficiency. Each sample was analysed in triplicate, and the expression was calculated according to the $2^{-\Delta \Delta \mathrm{Ct}}$ method.

Analysis of miRNA location and putative ER binding sites in the regulatory region of the miRNA precursors miRIAD software, a web search tool designed to obtain integrated information about intragenic miRNA and their host genes, was used to know E2-induced miRNA location [23]. Moreover, in silico analysis of ER putative binding sites within the regulatory region of miRNA was performed by using available online bioinformatic tools. We used miRStart database [24] and Promoter 2.0 Prediction Server [25] to predict the transcription start site (TSS) of the specific miRNA. When using Promoter 2.0, sequences scoring above 1.0 (highly likely prediction), which contain about $95 \%$ of true promoter sequence, were chosen as the miRNA precursor TSS. Gene and up-stream sequences were obtained from Ensembl (release 87; Dec 2016) [26]. Then, JASPAR 2016 server was used to predict ER $\alpha$ and ER $\beta$ binding sites for binding motifs drawn from the JASPAR database [27].

\section{Statistical analysis}

Data from microRNA expression analysis were analysed by paired t-test. For multiple comparisons, ANOVA was used to determine the difference between groups. When an interaction effect was found, multiple comparisons using Bonferroni's test was performed. Data are expressed as mean $\pm \mathrm{SEM}$, and results were considered as significantly different using a $\mathrm{p}<0.05$. The statistical analysis was performed using PRISM 5 software (GraphPad Software Inc., San Diego, CA, USA).

\section{Results}

Global analysis of miRNA expression data by PCA and hierarchical clusters

Changes in miRNA expression profile induced by E2 indicated a global alteration of miRNA, and were analysed and compared to control samples by principal component analysis (PCA) and Hierarchical clustering (Fig. 2). PCA was performed to globally view the groups among the 8 samples in terms of the expression profile. Although samples are dispersed with each other, results showed E2-treated and non-treated (control) pools enclosed in two differentiated clusters, underlying differences in the expression patterns between both groups (Fig. 2A). This indicates that miRNA have similar and consistent expression patterns within each group, but are distinct from each other, demonstrating the profound impact of E2 treatment on miRNA expression in endothelial cells. Hierarchical clustering showed large similarities among different treated samples. However, 298 probe sets of small non-coding RNA were differentially expressed between both groups (Fig. 2B). 


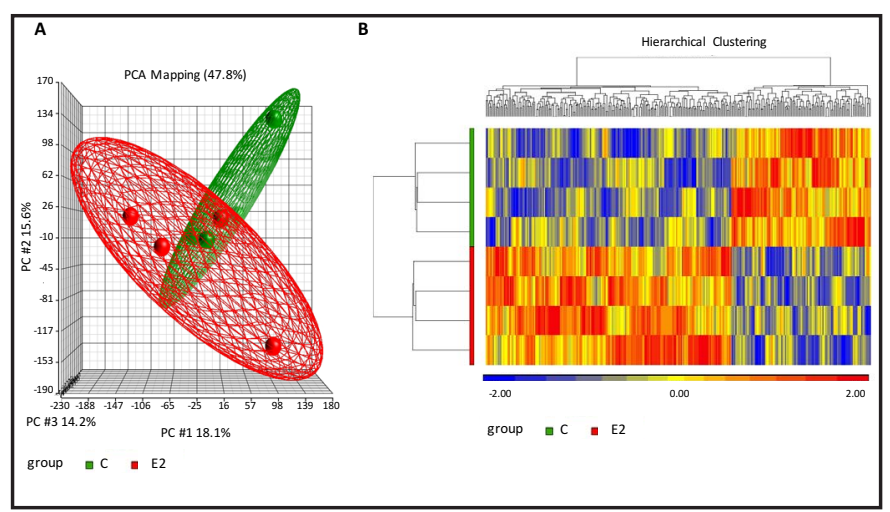

Fig. 2. Principal component analysis (PCA) and hierarchical cluster of E2 treated HUVEC. (A) PCA of miRNA expression profile of HUVEC treated with vehicle $(0.1 \%$ ethanol) or E2 $(1 \mathrm{nmol} / \mathrm{L})$ for $24 \mathrm{~h}$. (B) Hierarchical cluster of differentially expressed miRNA in HUVEC treated with vehicle $(0.1 \%$ ethanol) or E2 (1 nmol/L). Each column represents an individual probe set and each row represents a pool of cells. Control sample pools ( $C ; n=4)$ and E2 sample pools (E2; $n=4)$ were used.

We next explored those miRNA that were significantly regulated by $1 \mathrm{nmol} / \mathrm{L} \mathrm{E2}$, and we found that $114 \mathrm{miRNA}$ were differentially expressed compared to control cells, using a cut-off with adjusted $\mathrm{p}$ values of $<0.05$. In particular, 70 miRNA were up-regulated and 44 downregulated in HUVEC treated with E2 compared to control cells (Table 1). Microarray chips contained 2578 human mature miRNA probes, and therefore, approximately $4.4 \%$ of mature human miRNA were regulated by E2 in endothelial cells.

\section{In silico analysis of gene regulation by E2-modified miRNA}

IPA miRNA Target Filter tool was used to identify networks and pathways of the miRNA expression profile modified in HUVEC by E2. This software identified 112 of the 114 miRNA significantly modified by E2. Analysis of those 112 miRNA lead a total of 21748 either predicted or validated mRNA targets. In order to adopt a restrictive approach, we further filtered those mRNA targets by choosing only "the experimentally observed" and "highly predicted" target correlations, obtaining 5126 mRNA targeted by 112 miRNA. Using the selected miRNA-target pairing as an input, IPA revealed the most impacted biological processes, including cell death and survival, cellular assembly and organization, molecular transport, cell cycle, as well as cellular morphology and movement (listed in Table 2). Lipid and carbohydrate metabolism have also been included among the most regulated networks. In addition, reproductive, auditory-vestibular and cardiovascular system development and function appeared also as regulated by E2-dependent miRNA. Relationships to diseases and disorders including infection diseases, gastrointestinal disease, cancer, cardiovascular diseases and dermatological diseases were also noted.

Table 1. Significant regulated miRNA in E2-exposed HUVEC. The 114 miRNA significantly regulated by $1 \mathrm{nmol} / \mathrm{L}$ E2 were ordered according to their statistical significance in the microarray analysis. The list include miRNA that were both up-regulated (positive foldchange) and down-regulated (negative fold-change) by E2

\begin{tabular}{|c|c|c|c|}
\hline miRNA ID & Accession & $\mathrm{p}$-value & Fold change \\
\hline hsa-miR-6754-3p & MIMAT0027409 & 0,0013 & 1,57 \\
\hline hsa-miR-6839-3p & MIMAT0027581 & 0,0023 & $-1,14$ \\
\hline hsa-miR-501-3p & MIMAT0004774 & 0,0025 & 1,77 \\
\hline hsa-miR-548al & MIMAT0019024 & 0,0037 & $-1,20$ \\
\hline hsa-miR-219a-5p & MIMAT0000276 & 0,0038 & 1,16 \\
\hline hsa-miR-6721-5p & MIMAT0025852 & 0,0041 & 1,34 \\
\hline hsa-miR- $548 c-3 p$ & MIMAT0003285 & 0,0047 & 1,13 \\
\hline hsa-miR-3170 & MIMAT0015045 & 0,0055 & $-1,15$ \\
\hline hsa-miR-577 & MIMAT0003242 & 0,0057 & $-1,18$ \\
\hline hsa-miR-526b-3p & MIMAT0002836 & 0,0059 & $-1,15$ \\
\hline hsa-miR-1244 & MIMAT0005896 & 0,0059 & $-1,76$ \\
\hline hsa-miR-3975 & MIMAT0019360 & 0,0061 & 1,24 \\
\hline hsa-miR-487a-5p & MIMAT0026559 & 0,0062 & 1,94 \\
\hline hsa-miR-6866-3p & MIMAT0027633 & 0,0073 & $-1,24$ \\
\hline hsa-miR-623 & MIMAT0003292 & 0,0077 & $-1,16$ \\
\hline hsa-miR-6871-3p & MIMAT0027643 & 0,0080 & $-1,14$ \\
\hline hsa-miR-26a-5p & MIMAT0000082 & 0,0085 & 1,20 \\
\hline hsa-miR-6848-5p & MIMAT0027596 & 0,0093 & 1,21 \\
\hline hsa-miR- $6750-3 p$ & MIMAT0027401 & 0,0098 & 1,35 \\
\hline hsa-miR-6884-3p & MIMAT0027669 & 0,0108 & 1,47 \\
\hline hsa-miR-4797-3p & MIMAT0019973 & 0,0109 & 1,09 \\
\hline hsa-miR-520g-3p & MIMAT0002858 & 0,0109 & 1,29 \\
\hline hsa-miR-1224-3p & MIMAT0005459 & 0,0113 & $-1,21$ \\
\hline hsa-miR-1973 & MIMAT0009448 & 0,0123 & $-1,31$ \\
\hline hsa-miR-4491 & MIMAT0019026 & 0,0130 & 1,22 \\
\hline hsa-miR-3120-5p & MIMAT0019198 & 0,0142 & 1,14 \\
\hline hsa-miR-1303 & MIMAT0005891 & 0,0144 & 1,18 \\
\hline hsa-miR-3689f & MIMAT0019010 & 0,0145 & 1,30 \\
\hline hsa-miR-6782-5p & MIMAT0027464 & 0,0149 & 1,35 \\
\hline hsa-miR-937-3p & MIMAT0004980 & 0,0152 & $-1,13$ \\
\hline hsa-miR-7-2-3p & MIMAT0004554 & 0,0163 & $-1,15$ \\
\hline hsa-miR-4679 & MIMAT0019763 & 0,0165 & 1,16 \\
\hline hsa-miR-922 & MIMAT0004972 & 0,0165 & 1,18 \\
\hline hsa-miR-378h & MIMAT0018984 & 0,0169 & $-1,72$ \\
\hline hsa-miR-4429 & MIMAT0018944 & 0,0174 & $-1,40$ \\
\hline hsa-miR-5008-3p & MIMAT0021040 & 0,0174 & 1,23 \\
\hline hsa-miR-7158-5p & MIMAT0028226 & 0,0196 & 1,44 \\
\hline hsa-miR-4462 & MIMAT0018986 & 0,0197 & 1,42 \\
\hline hsa-miR-1296-5p & MIMAT0005794 & 0,0199 & 1,39 \\
\hline hsa-miR-512-3p & MIMAT0002823 & 0,0364 & 1,11 \\
\hline hsa-miR-5739 & MIMAT0023116 & 0,0365 & 1,18 \\
\hline hsa-miR-3124-5p & MIMAT0014986 & 0,0365 & 1,58 \\
\hline hsa-miR-4710 & MIMAT0019815 & 0,0379 & 1,88 \\
\hline hsa-miR-1294 & MIMAT0005884 & 0,0382 & 1,13 \\
\hline hsa-miR-6734-5p & MIMAT0027369 & 0,0385 & 1,53 \\
\hline hsa-miR-3622b-3p & MIMAT0018006 & 0,0396 & 1,23 \\
\hline hsa-miR-4680-3p & MIMAT0019765 & 0,0399 & $-1,09$ \\
\hline hsa-miR-553 & MIMAT0003216 & 0,0405 & $-1,20$ \\
\hline hsa-miR-876-5p & MIMAT0004924 & 0,0406 & 1,20 \\
\hline hsa-miR-6800-3p & MIMAT0027501 & 0,0415 & 1,67 \\
\hline hsa-miR-6747-3p & MIMAT0027395 & 0,0418 & $-1,21$ \\
\hline hsa-miR-3125 & MIMAT0014988 & 0,0421 & $-1,17$ \\
\hline hsa-miR-6512-5p & MIMAT0025480 & 0,0422 & 1,11 \\
\hline hsa-miR-6841-5p & MIMAT0027584 & 0,0431 & $-1,17$ \\
\hline hsa-miR-508-3p & MIMAT0002880 & 0,0435 & $-1,09$ \\
\hline hsa-miR-1302 & MIMAT0005890 & 0,0439 & $-1,29$ \\
\hline hsa-miR-506-5p & MIMAT0022701 & 0,0442 & $-1,33$ \\
\hline hsa-miR-30b-5p & MIMAT0000420 & 0,0445 & 2,02 \\
\hline hsa-miR-885-5p & MIMAT0004947 & 0,0446 & 1,42 \\
\hline hsa-miR-4769-3p & MIMAT0019923 & 0,0446 & 1,41 \\
\hline hsa-miR-1323 & MIMAT0005795 & 0,0446 & 1,24 \\
\hline hsa-miR-1193 & MIMAT0015049 & 0,0457 & 1,17 \\
\hline hsa-miR-5580-3p & MIMAT0022274 & 0,0459 & $-1,23$ \\
\hline hsa-miR-205-3p & MIMAT0009197 & 0,0459 & 1,06 \\
\hline hsa-miR-7849-3p & MIMAT0030424 & 0,0460 & 1,11 \\
\hline hsa-miR-383-3p & MIMAT0026485 & 0,0463 & $-1,17$ \\
\hline hsa-miR-126-3p & MIMAT0000445 & 0,0468 & 1,16 \\
\hline hsa-miR-7150 & MIMAT0028211 & 0,0470 & 1,32 \\
\hline hsa-miR-3620-3p & MIMAT0018001 & 0,0470 & 1,34 \\
\hline hsa-miR-634 & MIMAT0003304 & 0,0471 & $-1,33$ \\
\hline hsa-miR-6808-5p & MIMAT0027516 & 0,0477 & 1,65 \\
\hline hsa-miR-4759 & MIMAT0019905 & 0,0485 & $-1,22$ \\
\hline hsa-miR-6729-5p & MIMAT0027359 & 0,0486 & 1,16 \\
\hline hsa-miR-6746-3p & MIMAT0027393 & 0,0493 & 1,4 \\
\hline
\end{tabular}


Table 2. Regulatory networks modulated by E2-dependent miRNA. miRNA significantly regulated by E2 (1 $\mathrm{nmol} / \mathrm{L}$ ) were analysed using IPA software. The score is used to rank networks according to how relevant they are to the genes in the input dataset

\begin{tabular}{|c|c|c|c|}
\hline Top Diseases and Functions & Score & miRNA in Network & Predicted targets in Network \\
\hline $\begin{array}{l}\text { Cell Death and Survival, } \\
\text { Infectious Diseases, Organismal Development, }\end{array}$ & 27 & $\begin{array}{l}\text { miR-1294, miR-526b-3p, miR-30b-5p, } \\
\text { miR-3120-5p, miR-3620-3p, miR-3622b-3p, } \\
\text { miR-3680-3p, miR-3684, miR-374a-3p, } \\
\text { miR-37h, miR-457, miR-4he0, miR-5007-3p, } \\
\text { miR-501-3p, miR-520g-3p, miR-6746-3p }\end{array}$ & $\begin{array}{c}\text { ABCG2, CAMK2N1, CCDC70, CCNE2, CNKSR2, DCUN1D5, DQX1, FCH02, } \\
\text { GNA13, MDP1, NT5C3A, PAPD4, PDCDLLG2, PFN2, PMAIP1, RPL17- } \\
\text { C18orf32, RRAGD, SDAD1, VLDLR }\end{array}$ \\
\hline $\begin{array}{l}\text { Lipid Metabolism, Small Molecule Biochemistry, } \\
\text { Cellular Assembly and Organization }\end{array}$ & 21 & $\begin{array}{l}\text { miR-1205, miR-126a-3p, miR-219a-5p, } \\
\text { miR-383-3p, miR-4264, miR-4320, miR-448, } \\
\text { miR-4759, miR-4797-3p, miR-577, } \\
\text { miR-6841-5p, miR-876-5p, miR-92a-3p }\end{array}$ & $\begin{array}{l}\text { C17 orf80, CALCR, CLNS1A, ENPP6, FBX033, GNRH1, HSFY1/HSFY2, IGBP1, } \\
\text { KCNA4, MRPL33, MYO1B, NAP1L3, PI4KA, PTF1A, RGS3, SNTG2, T, TBX21, } \\
\text { UBE2W, VIL1, WFDC11, ZSCAN12 }\end{array}$ \\
\hline $\begin{array}{l}\text { Reproductive System Development and Function, } \\
\text { Organ Development, Developmental Disorder }\end{array}$ & 21 & $\begin{array}{c}\text { miR-1253, miR-1287-5p, miR-1296-5p, } \\
\text { miR-26a-5p, miR-6750-3p, miR-4491, } \\
\text { miR-4680-3p, miR-487a-5p, miR-5008-3p, } \\
\text { miR-506-5p, miR-1323, miR-5580-3p, } \\
\text { miR-7-2-3p }\end{array}$ & $\begin{array}{l}\text { ART3, ASB9, CHORDC1, EGFL6, ELSPBP1, GTF2A1L, LOC100131655, } \\
\text { MTERF4, PLAG1, PLGRKT, RPS27L, SMAD1, SNRNP48, SPDYA, SPINK13, } \\
\text { SPRR2B, SPRR2D, STON1-GTF2A1L, TDRD7, TGFBR2, TRIT1, ZBTB37 }\end{array}$ \\
\hline $\begin{array}{c}\text { Molecular Transport, Organismal Development, } \\
\text { Behaviour }\end{array}$ & 16 & $\begin{array}{c}\text { miR-1224-3p, miR-124-5p, miR-1303, } \\
\text { miR-3160-5p, miR-34c-3p, miR-3914, } \\
\text { miR-4769-3p, miR-548ae, miR-623, } \\
\text { miR-6839-3p, miR-4739 }\end{array}$ & $\begin{array}{l}\text { ABCD1, ARF6, ASAH2, BORCS6, BORCS8, BRMS1L, CARTPT, CD302, CRHBP, } \\
\text { DEFB134, GPKOW, IGSF23, IRF2BP2, KBTBD6, KLHL7, LANCL1, NUPL2, } \\
\text { PDGFRL, PDXP, RSU1, SLC13A3, TSSK3, TUBAL3, ZNF843 }\end{array}$ \\
\hline $\begin{array}{l}\text { Cell Cycle, Cellular Compromise, Cellular Function } \\
\text { and Maintenance }\end{array}$ & 16 & $\begin{array}{c}\text { miR-1263, miR-4298, miR-522-3p, miR-4685-5p, } \\
\text { miR-3689f, miR-4524b-5p, miR-4679, } \\
\text { miR-4778-5p, miR-548c-3p, miR-553, miR-5684 }\end{array}$ & $\begin{array}{l}\text { AKR1B10, ARMC10, C2CD4B, CPXM2, CSGALNACT2, CYTH3, DNASE2B, } \\
\text { FAM46D, GSTCD, HSPA13, KIAA1586, KRTAP20-2, NAA15, NAA30, NUDT9, } \\
\text { NUDT16L1, PHTF2, PPM1D, SFTPC, SLC22A7, SLC39A6, TCEA1, TRAK1, } \\
\text { VRK3 }\end{array}$ \\
\hline $\begin{array}{l}\text { Cell Morphology, Gastrointestinal Disease, } \\
\text { Organismal Injury and Abnormalities }\end{array}$ & 15 & $\begin{array}{c}\text { miR-6866-3p, miR-25-5p, miR-3124-5p, } \\
\text { miR-4429, miR-3682-3p, miR-4291, } \\
\text { miR-6512-5p, miR-626-3p, miR-6800-3p, } \\
\text { miR-922 }\end{array}$ & $\begin{array}{l}\text { ARPC5L, C17 orf49, C1QA, CASP1, COR06, DLEU2L, ERCC8, FGFBP1, HIPK2, } \\
\text { IL19, INO80C, JOSD2, KRTA24-1, NKX6-2, OPRM1, OSGEPL1, POLR1C, } \\
\text { RAB8A, RBM34, RGS22, TAPBP, TFF3, TMEM128, TMEM39A, TSSK6 }\end{array}$ \\
\hline $\begin{array}{l}\text { Cardiovascular Disease, Cancer, Dermatological } \\
\text { Diseases and Conditions }\end{array}$ & 15 & $\begin{array}{l}\text { miR-3936, miR-8089, miR-4710, miR-5588-3p, } \\
\text { miR-6734-5p, miR-6848-5p, miR-3125, } \\
\text { miR-7158-5p, miR-5739, miR-937-3p }\end{array}$ & $\begin{array}{l}\text { AOC2, ARHGEF6, ATE1, CCDC85A, DCAKD, DLK2, DMWD, FOXD3, GRAMD4, } \\
\text { HGS, HRC, LINC00346, MAPK15, ODF3L1, PEX19, PISD, PTCH1, PTCH2, } \\
\text { RIMBP3, SH2D3C, SNRPA, SPRED3, ZFAND2A, ZFYVE28, ZNF687 }\end{array}$ \\
\hline Auditory and Vestibular System Development and & 15 & miR-2052, miR-6871-3p, miR-3975, & AADACL4, ABHD18, ARSF, ATOH1, AZIN1-AS1, CCP110, CYP4F3, DDI1, \\
\hline $\begin{array}{l}\text { Cardiovascular Disease, Cardiovascular System } \\
\text { Development and Function, Organ Morphology }\end{array}$ & 13 & $\begin{array}{l}\text { miR-1973, miR-3170, miR-548al, miR-6729-5p, } \\
\text { miR-6721-5p, miR-6808-5p, miR-6884-3p, } \\
\text { miR-6886-5p, miR-7150 }\end{array}$ & $\begin{array}{l}\text { CCDC12, COX412, FBXO46, GALNS, GLIS1, HAS2, HRH1, IFITM3, ITPKB, } \\
\text { JADE2, KIF17, LCE5A, LY6L, MAF1, MAP2K2, MLLT1, NANOG, POR, PRAP1, } \\
\text { TCF7L1, TGM6, TROAP, TRPC4AP, TUBB8, VANGL1, XPC }\end{array}$ \\
\hline Cell Cycle, Cellular Movement, Cancer & 13 & $\begin{array}{l}\text { miR-1244, miR-205-3p, miR-130a-5p, } \\
\text { miR-302b-5p, miR-6754-3p, miR-4462, } \\
\text { miR-6747-3p, miR-7849-3p, miR-885-5p }\end{array}$ & $\begin{array}{l}\text { BOD1, CLDN12, COMMD9, CYYR1, EIF1AY, EXOC1, KMT5A, LRRIQ4, MOG, } \\
\text { PARL, PDK4, PROK2, RPS19BP1, RSPH10B/RSPH10B2, ST6GALNAC3, } \\
\text { STARD3NL, STX12, THAP12, TMEM70, ZAR1L, ZDBF2, ZNF141, ZNF486, } \\
\text { ZNF676, ZNF682, ZNF728 }\end{array}$ \\
\hline
\end{tabular}

Table 3. Top 10 cardiovascular related Canonical Pathways regulated by E2-dependent miRNA. Selection and functional characterization of predicted target genes assigned to cardiovascular pathways were performed by IPA software and the top 10 were ordered according to their $\mathrm{p}$ value. Ratio represents the number of target genes from the data set that map to the pathway divided by the total number of genes that map to a specific canonical pathway. Number of target genes assigned to each canonical pathway are shown

\begin{tabular}{|c|c|c|c|c|}
\hline & Canonical Pathways & $-\log (\mathrm{p}$-value) & Ratio & Number of target genes \\
\hline 1 & Cardiac Hypertrophy Signalling & 131.0 & 0.50 & 118 \\
\hline 2 & Role of NFAT in Cardiac Hypertrophy & 116.0 & 0.53 & 104 \\
\hline 3 & Thrombin Signalling & 106.0 & 0.48 & 98 \\
\hline 4 & CXCR4 Signalling & 86.0 & 0.49 & 80 \\
\hline 5 & Endothelin-1 Signalling & 85.2 & 0.44 & 83 \\
\hline 6 & Role of Macrophages, Fibroblasts and Endothelial Cells in Rheumatoid Arthritis & 83.9 & 0.32 & 100 \\
\hline 7 & Phospholipase C Signalling & 83.6 & 0.38 & 91 \\
\hline 8 & Protein Kinase A Signalling & 81.6 & 0.27 & 107 \\
\hline 9 & Production of Nitric Oxide and Reactive Oxygen Species in Macrophages & 79.1 & 0.42 & 80 \\
\hline 10 & Signalling by Rho Family GTPases & 75.9 & 0.34 & 85 \\
\hline
\end{tabular}

To explore the impact of E2-regulated miRNA in the context of our study, predicted target genes assigned to cardiovascular pathways by IPA software were selected and in silico functional characterization was performed. Top ten cardiovascular canonical pathways are listed in Table 3 in the order of $p$ values. IPA software also determines significance of the association between the data set and a specific canonical pathway based on a ratio between the number of target genes from the data set that map to the pathway divided by the total number of genes that map to a specific canonical pathway. Ratios of most regulated canonical pathway are also shown in Table 3.

Target genes regulated by E2-dependent miRNA were associated to specific canonical pathways. The top pathways are related to cardiac hypertrophy (118 genes), including signalling and the role of NFAT (104 genes). The top network generated by IPA revealed the interactions of altered miRNA with signalling pathways such as thrombin (98 genes), CXCR4 
(80 genes), phospholipase C (91 genes), protein kinase A (107 genes) and Rho GTPases (85 genes). Moreover, the role of macrophages, fibroblasts and endothelial cells (100 genes) also appear between the main regulated pathways. Additionally, E2-regulated miRNA were related to endothelin-1 signalling (83 genes), nitric oxide (NO) and reactive oxygen species production ( 80 genes), key vasoactive compounds in the regulation of endothelial homeostasis that are usually related to the vascular effects of estrogens.

\section{miRNA expression profiling and microarray validation}

As describe above, differences between miRNA profiling of human endothelial cells exposed during 24 hours with or without $1 \mathrm{nmol} / \mathrm{L}$ E2 revealed a total of 114 miRNA significantly regulated, with fold changes ranging from -1.76 to 2.02. Fig. 3A shows the most differentially expressed miRNA with a fold-change greater than 1.5. Thirteen miRNA were differentially regulated by E2 with this fold-change selected, including 10 up-regulated and 3 down-regulated miRNA. In order to validate our findings, qRT-PCR was performed using independently obtained RNA samples different from those used in microarray experiment. The most differentially expressed miRNA obtained in microarrays (miR-30b, miR-487a, miR4710, miR-501, miR-378h and miR-1244) were chosen and analysed by qRT-PCR. Obtained results confirmed microarray data of miRNA chosen for testing, including E2-dependent up-regulation of 4 miRNA (miR-30b, miR-487a, miR-4710 and miR-501) and the downregulation of 2 miRNA (miR-378h and miR-1244) (Fig. 3B).

Genomic location of validated E2-regulated miRNA.

As described before, miRNA sequences can be located in intronic regions of non-coding or coding transcripts, but it can be also encoded by exonic regions. We used miRIAD software to search genomic location of E2-dependent miRNA precursors. Table 4 shows chromosomic location and information about the host genes of intragenic miRNA. It is worthy to note that mature hsa-miR-1244 have 4 precursors sequences located in 3 different chromosomes.

Among the miRNA regulated by E2, there are 5 miRNA precursor sequences located between gene sequences and 4 intragenic miRNA precursor sequences: hsa-miR-501, hsamiR-378h and hsa-miR-1244-2 are intronic miRNA whereas hsa-miR-1244-1 is an exonic miRNA. Host genes of intragenic miRNA are also shown in Table 4: hsa-miR-501 is located in CLCN5, hsa-miR-378h in FAXDC2, hsa-miR-1244-1 in PTMA and hsa-miR-1244-2 in DTWD2.

\section{Role of estrogen receptors in E2-modified miRNA}

To study the role of ER in the expression of E2-dependent miRNA, both computational and experimental approaches were used. Firstly, we search in silico for putative ER binding

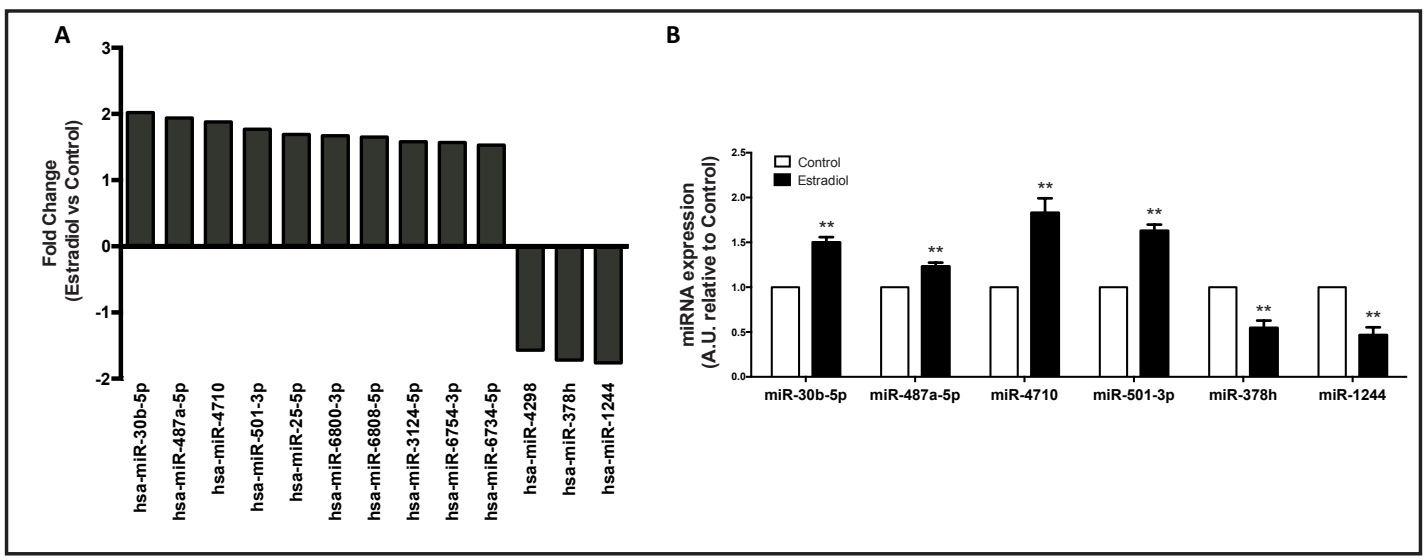

Fig. 3. Validation of microarray data of E2-regulated miRNA in HUVEC. (A) miRNA expression profiling of differentially expressed miRNA obtained by microarray (fold change $>1.5$ ) in E2-treated HUVEC. Results are shown as fold change of 4 independent experiments. (B) The most regulated miRNA by E2 in HUVEC selected from microarray data were validated by qRT-PCR as described in Material and Methods. Results are mean \pm SEM of $\mathrm{n}=8-12$ values from 3 to 5 independent experiments. ${ }^{* *} \mathrm{p}<0.01$ vs. control. 
sites in the regulatory region of miRNA precursors. Also, pharmacological treatment of endothelial cells with ER antagonists and agonists was performed to evaluate the role of ER in E2-regulated miRNA.

Available online bioinformatics tools were used to search for ER putative binding sites within the regulatory region of miRNA, focused on the ER mainly acting as transcription factors (ER $\alpha$ and ER $\beta$ ). We used miRStart database to predict the transcription start site (TSS) of the E2-regulated miRNA. Then, JASPAR 2016 server was used to predict $\mathrm{ER} \alpha$ and $\mathrm{ER} \beta$ binding sites for binding motifs drawn from the JASPAR database (Fig. 4A). TSS of hsa-miR-4710, hsamiR-378h and hsa-miR-1244-4 were not found in miRStart database, and were predicted using Promoter 2.0 Prediction Server. The location of TSS of the validated E2-regulated miRNA ranged from $109 \mathrm{bp}$ distance from the precursor sequence of miR1244-2 up to 31696 bp distance from the miR-30b precursor (Fig. 4B).

To predict ER binding sites in the promoter region of E2regulated miRNA, regulatory region was established based on genomic locality, upstream less than $10 \mathrm{~kb}$ from TSS. ER binding sites were found located in the regulatory region of all selected E2-regulated miRNA (Fig. 4B). Results showed a greater number of binding sites for ER $\beta$ than for ER $\alpha$ in the promoter region of selected miRNA precursors. However, since the sequence logo depicts the conservation of nucleotides in a specific position, the large number of ER $\beta$ binding sites found could be related to a greater variation observed in the sequence logo for the ER $\beta$ motif.

To evaluate experimentally the role of ER subtype in miRNA changes induced by E2, HUVEC were exposed to the non-selective antagonist of ER $\alpha$ and ER $\beta$, ICI $(1 \mu \mathrm{mol} / \mathrm{L})$, the specific ER $\alpha$ antagonist MPP (1 $\mu \mathrm{mol} / \mathrm{L})$ and the specific GPER antagonist G15 (1 $\mu \mathrm{mol} / \mathrm{L}$ ), before to E2 (1 nmol/L) exposition (Fig. 5). miR-30b-5p, miR-487a-5p and miR$378 \mathrm{~h}$ expression changes induced by E2 were abolished by ICI and MPP but not by G15 treatment. Decreased miR-1244 expression induced by E2 was abrogated by MPP but no by ICI antagonist or G15 treatment. These results suggest a predominant role of ER $\alpha$ in miR30b-5p, miR-487a-5p, miR-378h and miR-1244 regulation. The increment in miR-501-3p expression observed when HUVEC was exposed to $1 \mathrm{nmol} / \mathrm{L}$ E2 was reverted by using the unspecific ER antagonist, but not by MPP or G15. This finding suggests a possible role of ER $\beta$
Table 4. miRNA precursor location of E2-regulated miRNA. miAD searched the location of miRNA precursors of E2-

\begin{tabular}{lcccc}
\hline Symbol & Accession & Intragenic & $\begin{array}{c}\text { Location } \\
\text { Host gene }\end{array}$ & Chromosome \\
\hline hsa-mir-30b & MI0000441 & NO & - & 8 \\
hsa-mir-487a & MI0002471 & NO & - & 14 \\
hsa-mir-4710 & MI0017344 & NO & - & 14 \\
hsa-mir-501 & MI0003185 & YES & CLCN5 & X \\
hsa-mir-378h & MI0016808 & YES & FAXDC2 & 5 \\
hsa-mir-1244-1 & MI0006379 & YES & PTMA & 2 \\
hsa-mir-1244-2 & MI0015974 & YES & DTWD2 & 5 \\
hsa-mir-1244-3 & MI0015975 & NO & - & 12 \\
hsa-mir-1244-4 & MI0031511 & NO & - & 12 \\
\hline
\end{tabular}

\begin{tabular}{|c|c|c|c|c|}
\hline \multirow[t]{12}{*}{\begin{tabular}{|l} 
A \\
B
\end{tabular}} & \multicolumn{3}{|c|}{ 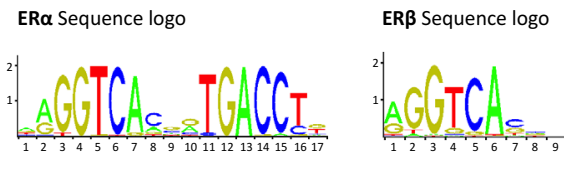 } & \\
\hline & \multirow{2}{*}{ Symbol } & \multirow{2}{*}{$\begin{array}{c}\text { TSS } \\
\text { (bp to precursor) }\end{array}$} & \multicolumn{2}{|c|}{ Binding sites } \\
\hline & & & ERo & ER $\beta$ \\
\hline & hsa-mir-30b & 31696 & 1 & 16 \\
\hline & hsa-mir-487a & 14000 & 2 & 41 \\
\hline & hsa-mir-4710 & 20600 & 4 & 54 \\
\hline & hsa-mir-501 & 5189 & 1 & 25 \\
\hline & hsa-mir-378h & 1900 & 2 & 34 \\
\hline & hsa-mir-1244-1 & 5129 & 2 & 46 \\
\hline & hsa-mir-1244-2 & 109 & 2 & 30 \\
\hline & hsa-mir-1244-3 & 110 & 3 & 25 \\
\hline & hsa-mir-1244-4 & 1000 & 3 & 28 \\
\hline
\end{tabular}

Fig. 4. Putative ER binding sites in the regulatory region of the precursors of E2-regulated miRNA. (A) ER $\alpha$ and ER $\beta$ binding sites miRStart and is presented as base pairs (bp) before precursor. The number of ER binding sites found in promoter region of E2regulated miRNA was found as stated in Material and methods section. for binding motifs were drawn from the JASPAR database. The higher size of the nucleotide symbol represents a higher strict 

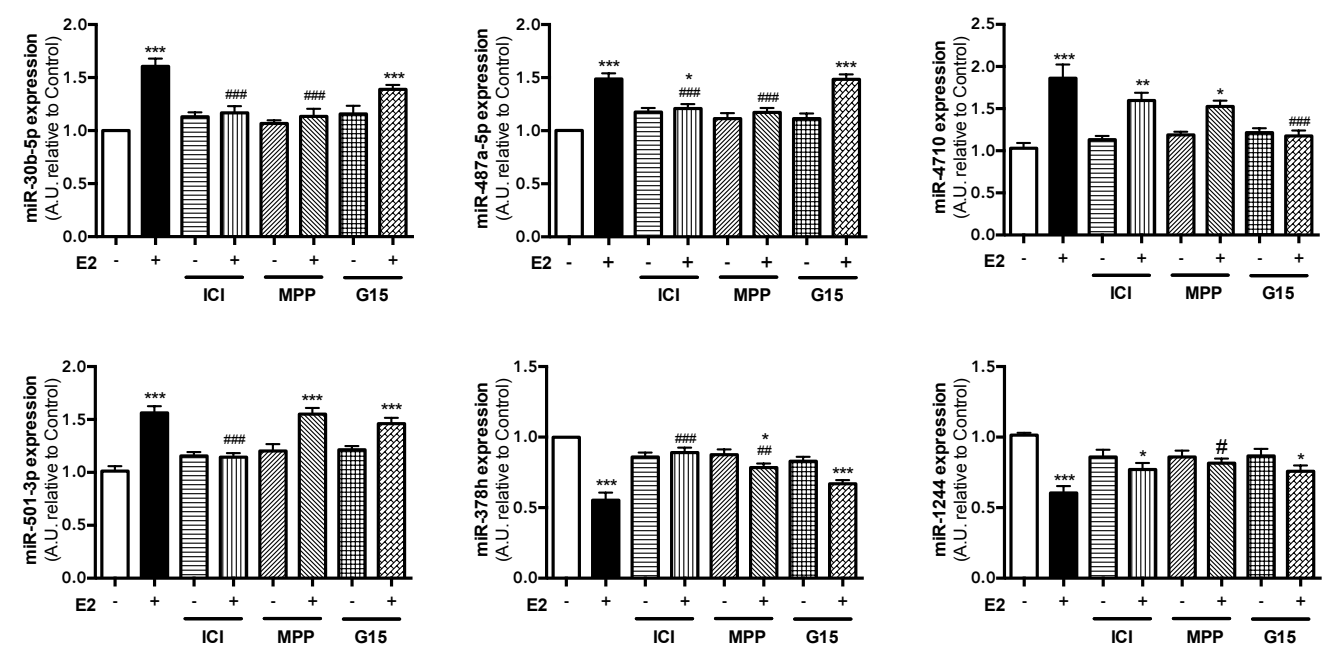

Fig. 5. Role of ER antagonists in miRNA expression. HUVEC were exposed to ICI ( $1 \mu \mathrm{mol} / \mathrm{L})$, MPP ( $1 \mu \mathrm{mol} / \mathrm{L})$ or G15 ( $1 \mu \mathrm{mol} / \mathrm{L})$ with or without E2 $(1 \mathrm{nmol} / \mathrm{L})$ for $24 \mathrm{~h}$. Relative miRNA expression was measured by qRT-PCR as described in Material and methods. Data are expressed as mean \pm SEM of $n=8-12$ from 3 to 5 independent experiments. ${ }^{*} \mathrm{p}<0.05$; ${ }^{* *} \mathrm{p}<0.01{ }^{* * *} \mathrm{p}<0.001$ vs. Control and ${ }^{\#} \mathrm{p}<0.05$; ${ }^{\# \#} \mathrm{p}<0.01$ vs. ${ }^{\# \#} \mathrm{p}<0.001$ vs. E2.
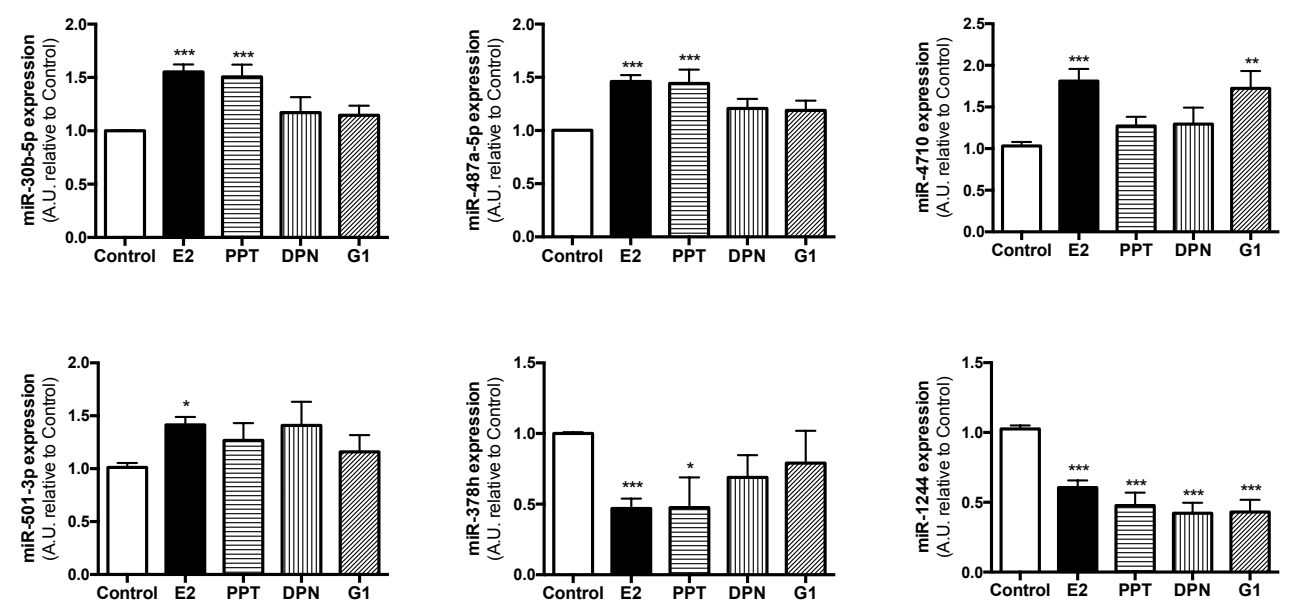

Fig. 6. Role of ER agonists in miRNA expression. HUVEC were exposed to E2 ( $1 \mathrm{nmol} / \mathrm{L}), \mathrm{PPT}(1 \mathrm{nmol} / \mathrm{L})$, DPN (1 nmol/L) or G1 (1 nmol/L) for $24 \mathrm{~h}$. Relative miRNA expression was measured by qRT-PCR as described in Material and methods. Data are expressed as mean \pm SEM of $n=8-12$ from 3 to 5 independent experiments. ${ }^{*} \mathrm{p}<0.05 ;{ }^{* * *} \mathrm{p}<0.01 ;{ }^{* * *} \mathrm{p}<0.001$ vs. Control.

in the regulation of miR-501-3p levels in HUVEC. Finally, neither ICI nor MPP exposition had effect counteracting the increase of miR-4710 observed after E2 exposition, and only G15 treatment abolished the E2-induced miR-4710 expression in HUVEC, suggesting the role of GPER in this expression.

Specific ER agonists were used to reinforce the role of specific ER in E2-regulated miRNA. HUVEC were exposed to the selective ER $\alpha$ agonist PPT $(1 \mathrm{nmol} / \mathrm{L})$, the selective ER $\beta$ agonist DPN ( $1 \mathrm{nmol} / \mathrm{L})$ and the selective GPER agonist G1 (1 nmol/L) for 24 hours and the expression of validated miRNA were measured by qRT-PCR and compared to the effect of E2 (1 nmol/L; Fig. 6). Exposition of PPT, but not DPN or G1, stimulate miR-30b-5p and 
miR-487a-5p expression. In addition, only PPT treatment decreased miR-378h levels. These findings are in agreement with results obtained using specific ER $\alpha$ antagonist and validate the role of ER $\alpha$ in the modulation of miR-30b-5p, miR-378h and miR-487a-5p. On the other hand, E2 induction of miR-4710 was mediated through GPER, since treatment with the specific GPER agonist G1 completely mimic E2 effect. Unpredictably, miR-501-3p expression was not significantly changed after isolated exposition with the different agonists. Finally, miR-1244 expression was decreased after exposition of the three different ER agonists.

\section{Discussion}

In the present study, we systematically investigated the role of $\mathrm{E} 2(1 \mathrm{nmol} / \mathrm{L})$ on miRNA profile in human endothelial cells by combining microarray technology with bioinformatics analysis. With those tools, we found that physiological concentration of E2 induces a change in miRNA expression profile, which combined with predicted target genes reveal a potential link between E2 and miRNA in the regulation of endothelial function. We also found that E2 effects on miRNA expression profile in HUVEC is differentially regulated by ER subtypes.

Functional in silico analysis of predicted targets ofE2-regulated miRNA identified different biological processes that could modify endothelial function, including cellular morphology and mobility, cell cycle, cell death and survival, lipid and carbohydrate metabolism. In that sense, accordingly to the role of E2 in endothelial cell movement previously published [28], it has been recently described that increase in cell migration and proliferation of E2-exposed HUVEC is mediated by miR-126-3p regulation [29]. Cell cycle, cell death and survival have also been ranked in the principal E2-regulated networks. Indeed, E2 has already been implicated in apoptosis via activation of miRNA-23a and p53 in liver cancer [30], and different profiles of estrogen-regulated miRNA in breast cancer cells have been described [31].

In addition, lipid and carbohydrate metabolism has also been included among the most regulated networks by miRNA, according to results derived from mRNA microarray previously published in HUVEC [5]. The effect of estrogens on lipid and carbohydrate metabolism has been previously described in postmenopausal women using estrogen replacement therapy [32], and actions triggered by ER have been involved in cellular metabolism in different tissues [33]. Since miRNA play a role in metabolic disorders [34], it is feasible that the modification of miRNA profile by E2 could be among the mechanisms by which estrogens regulate lipid metabolism.

Furthermore, development and functions of reproductive system is also, and expected, among the most significant networks regulated by E2. Estrogen action has been related to regulation of specific miRNA expression in the mouse uterus [35], and in humans, changes in miRNA expression has also been described along different phases of endometrium [22], suggesting a hormonal regulation of miRNA involved in endometrial cycle.

Among the pathways associated to cardiovascular pathways, that related to cardiac hypertrophy signal is the top ranked canonical pathway. Small and Olson reviewed the specific signature patterns of miRNA associated to different cardiovascular disorders, including cardiac hypertrophy [36]. Several studies have described sex-associated differences in gene and protein expression in the heart and have attributed those changes to the direct action of estrogens via either ER $\alpha$ or ER $\beta$ on mRNA transcription [37]. However, considering that miRNA play an important role in regulating gene expression, this could be a new mechanism by which estrogen would regulate cardiac morphology. In fact, it has been previously reported a sex-specific profile of miRNA expression mediated by ER $\beta$ in hypertrophied hearts [38].

During the progression of cardiovascular diseases, endothelial dysfunction is a critical player. Clinical and basic studies have established sex-associated differences in the regulation of endothelial function, and the modulatory role of estrogen on the endothelium have been well described. In this study, we described another mechanism by which estrogen could contribute to the regulation of endothelial function, that is, via miRNA modulation. Three of the most important vasoactive mediators produced by the endothelium such as 


\section{Cellular Physiology Cell Physiol Biochem 2018;45:1878-1892

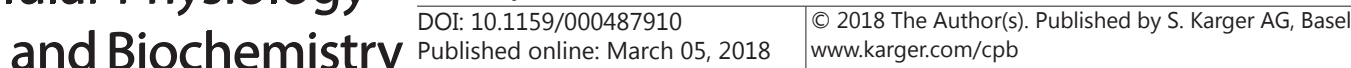 \\ Vidal-Gómez et al.: Estradiol Regulates Endothelial MiRNA}

NO, reactive oxygen species and endothelin-1 signalling, appear to be regulated by E2dependent miRNA. These results not only reinforce the role of E2 in NO stimulation, in the protection against reactive oxygen species and in the reduction of endothelin-1 [39], but also suggest new endothelial regulatory mechanisms by estrogens. Sex-differences in NO regulation by miRNA has been demonstrated in mouse hearts. The expression of miR-222 was decreased in females compared to males, and correlated with increased endothelial NO synthase expression in females [40]. In this direction, other studies also have described that estrogens stimulates ER $\alpha$-dependent inhibition of miR-22 expression, leading to an increase antioxidant activity in myocardium [41].

In the present study, we focused on miRNA that were highly changed after treatment with physiological concentration of E2 in HUVEC. Among the most modified miRNA, miR30b-5p, miR-487a-5p, miR-4710 and miR-501-3p were over-expressed after E2 treatment, while miR-378h and miR-1244 were down-regulated. miR-30b has been previously described as an estrogen-sensitive miRNA being increased by E2 treatment in breast cancer cells [42]. Moreover, miRNA profiling of human endometrium reveals cyclic changes in miR$30 \mathrm{~b}$ expression through the different physiological phases [43], and sex differences of miR$30 \mathrm{~b}$ levels were also observed in brains of female schizophrenic patients compared to males [44], suggesting the effect of physiological concentrations of estrogen on miR-30b regulation. In endothelial cells, miR-30 has also been implicated in angiogenesis processes [45], antiinflammatory effects by decreasing angiopoietin 2-induced VCAM1 expression [46] and apoptosis inhibition of human coronary artery endothelial cells [47]. In this regard, it is noteworthy that $\mathrm{E} 2$ has also pro-angiogenic, anti-inflammatory and anti-apoptotic properties in response to vascular injury [4]. miR-487a has been associated to the transforming growth factor $\beta 1$ (TGF- $\beta 1$ ) pathway $[48,49]$, a key cytokine in vascular function that has been previously related to estrogen action in endothelial cells [5]. On the other hand, our results showed miR-1244 as the most decreased miRNA in endothelial cells exposed to E2, which has been related to reduced migration of lung cancer cells [50]. As far as we know there is no published information about miRNA-1244, miR-501-3p, miR-4710 and miR-378h at cardiovascular level. However, miRNA-1244 is up-regulated in ER-compared to ER+ breast cancer cells [51], suggesting the role of estrogen receptor in decreasing miRNA-1244. miR501-3p has been related to pathological events occurring in Alzheimer disease brains [52].

The genomic effects of E2 are mainly mediated through the classical nuclear receptors $\mathrm{ER} \alpha$ and ER $\beta$, which function as ligand-activated transcription factors. In silico analysis of predicted target gene-transcription factor associations provided information about estrogen response element (ERE) sites in the regulatory region of the E2-regulated miRNA. ERE are 15 bp palindromic sequence with high affinity to ER which are conserved across species. In our results, ERE sites were found located in the regulatory region of all selected E2-regulated miRNA, suggesting that estrogen may be a regulator of those miRNA. Different studies provide data about distribution of ER binding sites in the regulatory regions of estrogenresponsive genes. Genome-wide mapping of ERE have shown that most of receptor binding sites were located close to TSS ( $1 \mathrm{~kb}$ ), but they also appeared up to $10 \mathrm{~kb}$ up-stream from TSS [53]. However, Carroll et al. found that only $4 \%$ of ER binding sites mapped were located to $1 \mathrm{~kb}$ promoter-proximal regions. Indeed, functional ER $\alpha$ binding sites have been described much further (up to $200 \mathrm{~kb}$ ) from the estrogen-regulated genes [54]. Meanwhile, it has been described that, in general, ER $\beta$-bound regions are located more closely to TSS [55].

Our results showed that E2-dependent regulation of the selected miRNA is mediated via ER. According to that, miRNA profiling between ER+ or ER- breast cancer cells revealed differences $[51,56]$. In fact, Bailey et al. demonstrated that ER binding sites located near miRNA are lost in differentially decreased miRNA in ER- breast cancer cell line [56]. We have also demonstrated the implication of specific ER in the selected E2-induced miRNA. Most of the analysed miRNA were regulated by ER $\alpha$, although ER $\beta$ and GPER were also involved in E2-regulated miRNA expression. Physiological responses require a balance between the activities of different ER, but several studies have reported differences in gene expression regulation mediated by either ER $\alpha$ or ER $\beta[57,58]$. Studies using ER $\alpha$ and ER $\beta$ KO mice reveal

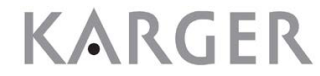


that the beneficial effects of estrogens on vascular system are mediated by ER $\alpha[58,59]$. It has been also reported that vascular smooth muscle cells proliferation is inhibited through an ER $\alpha$-dependent miR-203 up-regulation [60]. Specifically, estrogen action in endothelial cells is assumed to be mainly mediated by $\operatorname{ER} \alpha[6,7,28]$.

\section{Conclusion}

Data presented in this study provides a systematic analysis of miRNA expression profile by E2 in human endothelial cells. Identification of biological processes related to E2-regulated miRNA has been described and the role of ER in miRNA expression has been demonstrated. Our results indicate that miRNA may act as crucial epigenetic regulators of gene expression in E2-treated human endothelial cells and make an important contribution to future research focus on characterizing the role of specific miRNA in vascular actions mediated by E2. They also could provide insight into the mechanisms by which sex hormones levels can contribute to sex-differences in cardiovascular diseases.

\section{Acknowledgements}

This work was supported by Spanish Ministerio de Economía y Competitividad, Instituto de Salud Carlos III - FEDER-ERDF (grants PI13/00617, FIS PI16/00229, FIS PI16/00091, RD12/0042/0052 and RD12/0042/0006). D.P-C. is an "Atracció de Talent" fellow (grant number PREDOC13-110541, University of Valencia). A.M. is a "Formación de Profesorado Universitario" fellow (grant number FPU13/02235 Spanish Ministerio de Educación, Cultura y Deporte).

\section{Disclosure Statement}

The authors confirm that there are no conflicts of interest.

\section{References}

1 Mendelsohn ME: Mechanisms of estrogen action in the cardiovascular system. J Steroid Biochem Mol Biol 2000;74:337-343.

2 Chakrabarti S, Morton JS, Davidge ST: Mechanisms of Estrogen Effects on the Endothelium: An Overview. Can J Cardiol 2014;30:705-712.

-3 Mendelsohn ME, Karas RH: Molecular and Cellular Basis of Cardiovascular Gender Differences. Science 2005;308:1583-1587.

4 Xing D, Nozell S, Chen Y-F, Hage F, Oparil S: Estrogen and Mechanisms of Vascular Protection. Arterioscler Thromb Vasc Biol 2009;29:289-295.

-5 Sobrino A, Mata M, Laguna-Fernandez A, Novella S, Oviedo PJ, Garcia-Perez MA, Tarin JJ, Cano A, Hermenegildo C: Estradiol stimulates vasodilatory and metabolic pathways in cultured human endothelial cells. PLoS One 2009; 4:e8242.

6 Sobrino A, Oviedo PJ, Novella S, Laguna-Fernandez A, Bueno C, Garcia-Perez MA, Tarin JJ, Cano A, Hermenegildo C: Estradiol selectively stimulates endothelial prostacyclin production through estrogen receptor a. J Mol Endocrinol 2010;44:237-246.

7 Mompeón A, Lázaro-Franco M, Bueno-Betí C, Pérez-Cremades D, Vidal-Gómez X, Monsalve E, Gironacci MM, Hermenegildo C, Novella S: Estradiol, acting through ER $\alpha$, induces endothelial non-classic reninangiotensin system increasing angiotensin 1-7 production. Mol Cell Endocrinol 2016;422:1-8. 


\section{Cellular Physiology Cell Physiol Biochem 2018;45:1878-1892 \begin{tabular}{l|l|l} 
DOI: 10.1159/000487910 & $\begin{array}{l}\text { (c) } 2018 \text { The Author(s). Published by S. Karger AG, Basel } \\
\text { www.karger.com/cpb }\end{array}$
\end{tabular}

8 Mendell JT, Olson EN: MicroRNAs in Stress Signaling and Human Disease. Cell 2012;148:1172-1187.

-9 Bartel DP: MicroRNAs: Genomics, Biogenesis, Mechanism, and Function. Cell 2004;116:281-297.

10 Zhu H, Fan G-C: Extracellular/circulating microRNAs and their potential role in cardiovascular disease. Am J Cardiovasc Dis 2011;1:138-149.

-11 Xu J, Zhao J, Evan G, Xiao C, Cheng Y, Xiao J: Circulating microRNAs: novel biomarkers for cardiovascular diseases. J Mol Med 2012;90:865-875.

$\checkmark 12$ Schulte C, Zeller T: microRNA-based diagnostics and therapy in cardiovascular disease-Summing up the facts. Cardiovasc Diagn Ther 2015;5:17-36.

-13 Felty Q Yoo C, Kennedy A: Gene expression profile of endothelial cells exposed to estrogenic environmental compounds: Implications to pulmonary vascular lesions. Life Sci 2010;86:919-927.

14 Felty Q: Proteomic 2D DIGE profiling of human vascular endothelial cells exposed to environmentally relevant concentration of endocrine disruptor PCB153 and physiological concentration of $17 \beta$-estradiol. Cell Biol Toxicol 2011;27:49-68.

15 Barbano R, Pasculli B, Rendina M, Fontana A, Fusilli C, Copetti M, Castellana S, Valori VM, Morritti M, Graziano P, Luigi C, Coco M, Picardo F, Mazza T, Evron E, Murgo R, Maiello E, Esteller M, Fazio VM, Parrella P: Stepwise analysis of MIR9 loci identifies miR-9-5p to be involved in Oestrogen regulated pathways in breast cancer patients. Sci Rep 2017;7:45283.

16 Zhu H, Dai M, Chen X, Chen X, Qin S, Dai S: Integrated analysis of the potential roles of miRNA-mRNA networks in triple negative breast cancer. Mol Med Rep 2017;16:1139-1146.

17 Monsalve E, Oviedo PJ, Garcia-Perez MA, Tarin JJ, Cano A, Hermenegildo C: Estradiol counteracts oxidized LDL-induced asymmetric dimethylarginine production by cultured human endothelial cells. Cardiovasc Res 2007;73:66-72.

18 Sobrino A, Oviedo PJ, Novella S, Laguna-Fernandez A, Bueno C, Garcia-Perez MA, Tarin JJ, Cano A, Hermenegildo C: Estradiol selectively stimulates endothelial prostacyclin production through estrogen receptor a. J Mol Endocrinol 2010;44:237-246.

19 Mompeon A, Lazaro-Franco M, Bueno-Beti C, Perez-Cremades D, Vidal-Gomez X, Monsalve E, Gironacci MM, Hermenegildo C, Novella S: Estradiol, acting through ERalpha, induces endothelial non-classic reninangiotensin system increasing angiotensin 1-7 production. Mol Cell Endocrinol 2016;422:1-8.

20 Zhu Y, Kawaguchi K, Kiyama R: Differential and directional estrogenic signaling pathways induced by enterolignans and their precursors. PLoS One 2017;12:e0171390.

21 Downey T: Analysis of a Multifactor Microarray Study Using Partek Genomics Solution. Methods Enzymol 2006;411:256-270.

22 Altmae S, Martinez-Conejero JA, Esteban FJ, Ruiz-Alonso M, Stavreus-Evers A, Horcajadas JA, Salumets A: MicroRNAs miR-30b, miR-30d, and miR-494 regulate human endometrial receptivity. Reprod Sci 2013;20:308-317.

23 Hinske LC, França GS, Torres HAM, Ohara DT, Lopes-Ramos CM, Heyn J, Reis LFL, Ohno-Machado L, Kreth S, Galante PAF: miRIAD—integrating microRNA inter- and intragenic data. Database 2014;2014:bau099.

-24 Chien C-H, Sun Y-M, Chang W-C, Chiang-Hsieh P-Y, Lee T-Y, Tsai W-C, Horng J-T, Tsou A-P, Huang H-D: Identifying transcriptional start sites of human microRNAs based on high-throughput sequencing data. Nucleic Acids Res 2011;39:9345-9356.

25 Knudsen S: Promoter2.0: for the recognition of PolII promoter sequences. Bioinformatics 1999;15:356361.

26 Yates A, Akanni W, Amode MR, Barrell D, Billis K, Carvalho-Silva D, Cummins C, Clapham P, Fitzgerald S, Gil L, Girón CG, Gordon L, Hourlier T, Hunt SE, Janacek SH, Johnson N, Juettemann T, Keenan S, Lavidas I, Martin FJ, Maurel T, McLaren W, Murphy DN, Nag R, Nuhn M, Parker A, Patricio M, Pignatelli M, Rahtz M, Riat HS, Sheppard D, Taylor K, Thormann A, Vullo A, Wilder SP, Zadissa A, Birney E, Harrow J, Muffato M, Perry E, Ruffier M, Spudich G, Trevanion SJ, Cunningham F, Aken BL, Zerbino DR, Flicek P: Ensembl 2016 Nucleic Acids Res 2016;44:D710-D716.

27 Mathelier A, Fornes O, Arenillas DJ, Chen C-y, Denay G, Lee J, Shi W, Shyr C, Tan G, Worsley-Hunt R, Zhang AW, Parcy F, Lenhard B, Sandelin A, Wasserman WW: JASPAR 2016: a major expansion and update of the open-access database of transcription factor binding profiles. Nucleic Acids Res 2016;44:D110-D115.

-28 Oviedo PJ, Sobrino A, Laguna-Fernandez A, Novella S, Tarín JJ, García-Pérez M-A, Sanchís J, Cano A, Hermenegildo C: Estradiol induces endothelial cell migration and proliferation through estrogen receptorenhanced RhoA/ROCK pathway. Mol Cell Endocrinol 2011;335:96-103. 


\section{Cellular Physiology Cell Physiol Biochem 2018;45:1878-1892 \\ \begin{tabular}{l|l} 
and Biochemistry Published online: March 05, 2018 & $\begin{array}{l}\text { (c) 2018 The Author(s). Published by S. Karger AG, Basel } \\
\text { www.karger.com/cpb }\end{array}$
\end{tabular} \\ Vidal-Gómez et al.: Estradiol Regulates Endothelial MiRNA}

29 Li P, Wei J, Li X, Cheng Y, Chen W, Cui Y, Simoncini T, Gu Z, Yang J, Fu X: 17 $\beta$-Estradiol Enhances Vascular Endothelial Ets-1/miR-126-3p Expression: The Possible Mechanism for Attenuation of Atherosclerosis. J Clin Endocrinol Metab 2017;102:594-603.

-30 Huang F-Y, Wong DK-H, Seto W-K, Lai C-L, Yuen M-F: Estradiol induces apoptosis via activation of miRNA23a and p53: implication for gender difference in liver cancer development. Oncotarget 2015;6:3494134952.

-31 Muluhngwi P, Klinge CM: Roles for miRNAs in endocrine resistance in breast cancer. Endocr Relat Cancer 2015;22:R279-R300.

-32 Salpeter SR, Walsh JM, Ormiston TM, Greyber E, Buckley NS, Salpeter EE: Meta-analysis: effect of hormonereplacement therapy on components of the metabolic syndrome in postmenopausal women. Diabetes Obes Metab 2006;8:538-554.

-33 Barros RP, Gustafsson JA: Estrogen receptors and the metabolic network. Cell Metab 2011;14:289-299.

-34 Fernandez-Hernando C, Ramirez CM, Goedeke L, Suarez Y: MicroRNAs in metabolic disease. Arterioscler Thromb Vasc Biol 2013;33:178-185.

-35 Nothnick WB, Healy C: Estrogen induces distinct patterns of microRNA expression within the mouse uterus. Reprod Sci 2010;17:987-994.

-36 Small EM, Olson EN: Pervasive roles of microRNAs in cardiovascular biology. Nature 2011;469:336-342.

-37 Murphy E, Steenbergen C: Estrogen regulation of protein expression and signaling pathways in the heart. Biol Sex Differ 2014;5:6.

-38 Queirós AM, Eschen C, Fliegner D, Kararigas G, Dworatzek E, Westphal C, Sanchez Ruderisch H, RegitzZagrosek V: Sex- and estrogen-dependent regulation of a miRNA network in the healthy and hypertrophied heart. Int J Cardiol 2013;169:331-338.

-39 Alvarez A, Hermenegildo C, Issekutz AC, Esplugues JV, Sanz MJ: Estrogens inhibit angiotensin IIinduced leukocyte-endothelial cell interactions in vivo via rapid endothelial nitric oxide synthase and cyclooxygenase activation. Circ Res 2002;91:1142-1150.

40 Evangelista AM, Deschamps AM, Liu D, Raghavachari N, Murphy E: miR-222 contributes to sex-dimorphic cardiac eNOS expression via ets-1 Physiol Genomics 2013;45:493-498.

41 Wang L, Tang ZP, Zhao W, Cong BH, Lu JQ, Tang XL, Li XH, Zhu XY, Ni X: MiR-22/Sp-1 Links Estrogens With the Up-Regulation of Cystathionine gamma-Lyase in Myocardium, Which Contributes to Estrogenic Cardioprotection Against Oxidative Stress. Endocrinology 2015;156:2124-2137.

42 Bhat-Nakshatri P, Wang G, Collins NR, Thomson MJ, Geistlinger TR, Carroll JS, Brown M, Hammond S, Srour EF, Liu Y, Nakshatri H: Estradiol-regulated microRNAs control estradiol response in breast cancer cells. Nucleic Acids Res 2009;37:4850-4861.

43 Kuokkanen S, Chen B, Ojalvo L, Benard L, Santoro N, Pollard JW: Genomic Profiling of MicroRNAs and Messenger RNAs Reveals Hormonal Regulation in MicroRNA Expression in Human Endometrium. Biol Reprod 2010;82:791-801.

-44 Mellios N, Galdzicka M, Ginns E, Baker SP, Rogaev E, Xu J, Akbarian S: Gender-Specific Reduction of Estrogen-Sensitive Small RNA, miR-30b, in Subjects With Schizophrenia. Schizophr Bull 2012;38:433-443.

-45 Bridge G, Monteiro R, Henderson S, Emuss V, Lagos D, Georgopoulou D, Patient R, Boshoff C: The microRNA-30 family targets DLL4 to modulate endothelial cell behavior during angiogenesis. Blood 2012;120:5063-5072.

46 Demolli S, Doebele C, Doddaballapur A, Lang V, Fisslthaler B, Chavakis E, Vinciguerra M, Sciacca S, Henschler R, Hecker M, Savant S, Augustin HG, Kaluza D, Dimmeler S, Boon RA: MicroRNA-30 mediates anti-inflammatory effects of shear stress and KLF2 via repression of angiopoietin $2 \mathrm{~J}$ Mol Cell Cardiol 2015;88:111-119.

47 Li F, Chen Q, Song X, Zhou L, Zhang J: MiR-30b Is Involved in the Homocysteine-Induced Apoptosis in Human Coronary Artery Endothelial Cells by Regulating the Expression of Caspase 3. Int J Mol Sci 2015;16:17682-17695.

48 Wang J, Pei Y, Zhong Y, Jiang S, Shao J, Gong J: Altered Serum MicroRNAs as Novel Diagnostic Biomarkers for Atypical Coronary Artery Disease. PLoS One 2014;9:e107012.

-49 Ma M, He M, Jiang Q Yan Y, Guan S, Zhang J, Yu Z, Chen Q Sun M, Yao W, Zhao H, Jin F, Wei M: MiR-487a Promotes TGF- $\beta 1$-induced EMT, the Migration and Invasion of Breast Cancer Cells by Directly Targeting MAGI2. Int J Biol Sci 2016;12:397-408. 


\section{Cellular Physiology Cell Physiol Biochem 2018;45:1878-1892

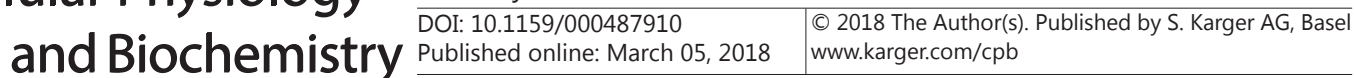 \\ Vidal-Gómez et al.: Estradiol Regulates Endothelial MiRNA}

50 Li W, Wang W, Ding M, Zheng X, Ma S, Wang X: MiR-1244 sensitizes the resistance of non-small cell lung cancer A549 cell to cisplatin. Cancer Cell Int 2016;16:30.

51 Cizeron-Clairac G, Lallemand F, Vacher S, Lidereau R, Bieche I, Callens C: MiR-190b, the highest upregulated miRNA in ER $\alpha$-positive compared to ER $\alpha$-negative breast tumors, a new biomarker in breast cancers? BMC Cancer 2015;15:499.

\$2 Hara N, Kikuchi M, Miyashita A, Hatsuta H, Saito Y, Kasuga K, Murayama S, Ikeuchi T, Kuwano R: Serum microRNA miR-501-3p as a potential biomarker related to the progression of Alzheimer's disease. Acta Neuropathol Commun 2017;5:10.

53 Bourdeau V, Deschenes J, Metivier R, Nagai Y, Nguyen D, Bretschneider N, Gannon F, White JH, Mader $\mathrm{S}$ : Genome-wide identification of high-affinity estrogen response elements in human and mouse. Mol Endocrinol 2004;18:1411-1427.

54 Carroll JS, Meyer CA, Song J, Li W, Geistlinger TR, Eeckhoute J, Brodsky AS, Keeton EK, Fertuck KC, Hall GF, Wang Q, Bekiranov S, Sementchenko V, Fox EA, Silver PA, Gingeras TR, Liu XS, Brown M: Genome-wide analysis of estrogen receptor binding sites. Nat Genet 2006;38:1289-1297.

55 Liu Y, Gao H, Marstrand TT, Strom A, Valen E, Sandelin A, Gustafsson JA, Dahlman-Wright K: The genome landscape of ERalpha- and ERbeta-binding DNA regions. Proc Natl Acad Sci U S A 2008;105:2604-2609.

56 Bailey ST, Westerling T, Brown M: Loss of estrogen-regulated microRNA expression increases HER2 signaling and is prognostic of poor outcome in luminal breast cancer. Cancer Res 2015;75:436-445.

57 O’Lone R, Knorr K, Jaffe IZ, Schaffer ME, Martini PG, Karas RH, Bienkowska J, Mendelsohn ME, Hansen U: Estrogen receptors alpha and beta mediate distinct pathways of vascular gene expression, including genes involved in mitochondrial electron transport and generation of reactive oxygen species. Mol Endocrinol 2007;21:1281-1296.

58 Arnal JF, Fontaine C, Billon-Gales A, Favre J, Laurell H, Lenfant F, Gourdy P: Estrogen receptors and endothelium. Arterioscler Thromb Vasc Biol 2010;30:1506-1512.

59 Pare G, Krust A, Karas RH, Dupont S, Aronovitz M, Chambon P, Mendelsohn ME: Estrogen receptor-alpha mediates the protective effects of estrogen against vascular injury. Circ Res 2002;90:1087-1092.

60 Zhao J, Imbrie GA, Baur WE, Iyer LK, Aronovitz M, Kershaw TB, Haselmann GM, Lu Q Karas RH: Estrogen receptor-mediated regulation of microRNA inhibits proliferation of vascular smooth muscle cells. Arterioscler Thromb Vasc Biol 2013;33:257-265. 